\title{
Water Conservation: An Emerging but Vital Issue in Hemodialysis Therapy
}

\author{
Faissal Tarrass $^{a}$ Meryem Benjelloun ${ }^{a}$ Omar Benjelloun ${ }^{c}$ Tarik Bensaha ${ }^{b}$ \\ a Department of Hemodialysis, Larache Hospital Center, Larache, and ${ }^{b}$ Stomatologist and Water Conservation \\ Researcher, Tangiers, Morocco; ' $D$ Department of Nephrology, Hospital Universitario Central de Asturias, \\ Oviedo, Spain
}

\section{Key Words}

Hemodialysis • Reverse osmosis - Water conservation •

Water reuse $\cdot$ Environment $\cdot$ Financial savings

\begin{abstract}
Water conservation refers to reducing the usage of water and recycling of wastewater for different purposes such as irrigation, laundry and sanitation. As water scarcity increases worldwide, dialysis facilities should be focused on salvaging water. However, most of them still ignorantly discard to the sewer huge volumes of this reusable resource. This article reviews the current water conservation techniques in hemodialysis and the potential benefits drawn when using this technology.

Copyright $\odot 2010$ S. Karger AG, Basel
\end{abstract}

\section{Introduction}

Water is becoming a dwindling natural resource due to global warming, climate change and recurring droughts; in fact, it is too valuable to waste [1-3]. Hemodialysis uses large volumes of water. In a patient undergoing weekly dialysis treatment 3 times for $4 \mathrm{~h}$, about 18,000 liters of dialysis fluid is used [4]. In addition, for each liter of usable water to make up the dialysis fluid, up to $25 \%$ of the water entering the water treatment system may be sent to the drain [5].

\section{KARGER \\ Fax +4161306 1234 E-Mail karger@karger.ch} www.karger.com
Due to the increasing scarcity of water worldwide, questions are beginning to be raised as to whether some of this water may be reused $[2,4,6]$. With regard to conservation and reuse of water, 2 aspects need to be considered: can less water be used during the treatment, and can water rejected by reverse osmosis (RO) and the spent dialysis fluid be reused?

Hemodialysis water conservation projects have been shown to be associated with important environmental and financial savings [2, 7-9]. However, the published literature on this subject is very limited. This article reviews the current water conservation measures in hemodialysis and potential financial and environmental benefits of using these techniques.

\section{Water: A Valuable Resource under Threat}

Water is one of our basic resources, but it is often in short supply. Estimates have shown that the total amount of water available would be sufficient to provide the present world population with only the minimum amount of freshwater required. However, the uneven distribution of water among regions has made the adequate supply critical for a growing number of countries [1]. Rapid population growth and increasing consumption rates of water per capita have aggravated the problem $[1,10]$. This tendency is likely to continue as water consumption for most uses is projected to increase by at least $50 \%$ by 2025 com-

Dr. Faissal Tarrass

2, Route Taddart

Rés Bughari $\mathrm{N}^{\circ} 7$

Casablanca 20100 (Morocco)

Tel. +212 6661494 94, E-Mail ftarrass@ hotmail.com 
pared to the 1995 level $[1,10]$. One additional reason for concern is climate change, which may lead to increased drought in many places $[10,11]$.

By 2025, 1.8 billion people will live in countries or regions with absolute water scarcity. Most countries in the Middle East and North Africa can be classified as having absolute water scarcity today. By 2025, these countries will be joined by Pakistan, South Africa and large parts of India and China. This means that they will not have sufficient water resources to maintain their current level of per capita food production from irrigated agriculture and also to meet reasonable water needs for domestic, industrial and environmental purposes $[10,11]$. As result, water should be sourced carefully.

\section{Water Utilization and Management in Hemodialysis}

Hemodialysis uses large amounts of water. Water is required to prepare dialysate, clean and reprocess machines and membranes. Prior to its use in hemodialysis, water has to be treated to remove particles, reduce hardness and remove inorganic ions from municipal water. The most commonly used water-purification systems in hemodialysis units consist of several components which are connected in line in order to improve water quality step by step. Water for hemodialysis generally requires $\mathrm{RO}$ treatment and a deionizer for 'polishing' the water. Organic materials, chlorine and chloramines are removed by charcoal filtration [5].

In hemodialysis, assuming a dialysate flow rate of 500 $\mathrm{ml} / \mathrm{min}$, a patient is exposed to 120 liters of purified water during a typical 4-hour dialysis session. Including priming and rinsing volumes, and depending on the efficiency of the RO system, approximately 500 liters of tapwater are required to produce sufficient high-grade water $[2,12]$. However, despite the increasing scarcity of water, most dialysis facilities still ignorantly discard huge volumes of this reusable resource to the sewer daily $[2,3,6,7,13]$.

\section{Water Consumption in Hemodialysis and Projected Potential Needs}

As our planet's population continues to grow, so does the sustainable growth rate of the dialysis patient population. The dialysis patient population growth annual rate is now expected to be $6 \%$, which will give us roughly 4 million patients by 2025 [14]. As the number of patients on dialysis continues to grow, so does the amount of nat- ural resources consumed and waste produced by dialysis facilities.

In the United States, the 5,000 dialysis clinics (which represent $26 \%$ of the global dialysis market) perform over 50 million dialysis treatments per year, consuming over 5 trillion liters of fresh water per year, based on its 325,000 patients in 2007 [12]. In Australia, an estimated 400 million liters (0.4 gigaliters) or 400 olympic-sized swimming pools of water disappear down the drain each year [13]. In Morocco, water consumption exceeds 190 million liters (50 million US gallons) of fresh water per year at hemodialysis facilities [2]. Therefore, due to this huge water consumption, dialysis centers should be focused on water conservation.

\section{Water Conservation Measures in Hemodialysis}

Approaches in configuring conventional water treatment equipment to meet water conservation, reduction and reuse can vary from one dialysis facility to another depending on the type, design of the installed RO system and the amount of water that the RO system processes. Approaches and techniques for salvaging water may range from simple methods such as $\mathrm{RO}$ system selection and design to redirection of reject water by $\mathrm{RO}$ or other more complicated techniques such as recycling of wastespent dialysate.

\section{RO System Selection}

Accurate RO system design, selection of membrane and proper pretreatment is critical to getting the most from your water treatment system. The amount of wasted water will vary with the configuration of the system. An oversized RO system can result in excessive waste of treated water and reject RO water [15]. Also, an oversized RO membrane needs high output and requires correspondingly high reject flow [16]. As a result, these factors must be considered when installing water treatment equipment.

The efficiency of an $\mathrm{RO}$ system is also dependent upon the nature of the feed water and temperature [4]. Temperature has an inverse effect on product flow through the membrane: high temperature increases product flow, low temperature decreases product flow. This can be reduced by the use of a dual-pass system in which the rejected water passes through the RO process before being discarded to waste [4]. Moreover, modern RO systems are generally more efficient and reject less water to drain [12]. 


\section{Water Flow Regulation}

A flow regulation device means a system fitted to the distribution loop to automatically adjust the flow of water to match the actual usage. As a result, less water is consumed and less reject is drained to the sewer by the RO system.

In hemodialysis, the fluid demand of machines is not constant and varies with the cycling of the machine [17]. Thus, flow regulators such as a valve (direct acting or pilot operated) could be used to regulate the flow rate of water according to water consumption by machines $[15$, 17]. As result, the RO module reduces water wastage by adjusting water production accordingly [15].

Printz [15] reported the benefits of using this technology in reducing waste from $\mathrm{RO}$ systems. Given an example of a facility working with 20 machines, on 2 sessions ( 4 h each) per day, 6 days per week, and on $50 \%$ of capacity 3 times per week, the reject RO water could be estimated at $1,372.8 \mathrm{~m}^{3} /$ year, although when using a motorized triple-way valve, the reject $\mathrm{RO}$ water decreased to $917.28 \mathrm{~m}^{3} /$ year, which results in direct water savings of $455.52 \mathrm{~m}^{3} /$ year [15].

\section{Recirculation of Excess Product Water}

Measures whereby the excess product water by RO system can be recirculated using a recirculation loop can also help conservation [5]. In direct water distribution systems that 'directly' deliver the product water from the $\mathrm{RO}$ unit to the loop for distribution, unused product water can be recirculated before the $\mathrm{RO}$ unit. In indirect water distribution systems which involve a storage tank that accumulates the product water and delivers it to the distribution loop, unused portions of the product water can be recirculated back into the storage tank. The RO unit will stop and start filling the tank by receiving signals from the high and low level switches on the storage tank which can result in water savings [5]. The recirculation of excess product does not only help conserve water, but also helps reduce stress on the RO membranes, increase permeate quality and lower operating costs [5].

\section{RO Reject Water Redirection or Reuse}

Rationale

$\mathrm{RO}$ is an important step in the water purification process. RO systems vary in efficiency, but commonly reject $25 \%$ of water presented to them $[5,18]$. In the current worldwide hemodialysis practice, considerable reject water is lost to drain. In the United States, the annual equivalent reject water generation would be approximately 27 gigaliters, which would be sufficient to provide all of the yearly water requirements for a city of approximately 175,000 , e.g. Salt Lake City, Utah [13].

Reject water is remarkably good water. Although this high-grade grey water is not legally acceptable for drinking, it commonly meets potable water criteria. It does not at any stage come into contact with the patient and therefore poses no infection risk [7]. As a result, dialysis facilities must be wise to pay attention to their water wastage, and particular consideration should be given to the possibility to benefit from this reject water.

Description of a Reusing/Redirecting Water System

In a typical water redirecting system, reject water from the RO unit generally flows to a storage tank and is then pumped for redistribution. The system is regulated by float switches and surplus water can be diverted to drain if there is no demand $[6,14]$.

Today, a number of dialysis facilities in Australia [7, 9, 19-24], the United States [25, 26], Canada [27], the United Kingdom [28], China [8, 29], France [30, 31], Spain [32] and Morocco use the reject water for irrigation, laundry, sanitation or for the generation of steam for the sterilization of hospital instruments and other sterile materials. Also, in home hemodialysis, reject $\mathrm{RO}$ water can be recycled at home installations to tank storage or for laundry use, toilet flushing, showering, livestock or garden/crop care, etc., according to patient's preference [6].

\section{Recycling Spent Dialysate Effluent}

In arid countries, water is becoming scarcer, and in fact too valuable to waste. In renal care practice, the dialysate effluent is uniformly drained to the sewer by all dialysis services worldwide. Tarrass et al. [2, 3], from Morocco, assessed the feasibility of using membrane technology to produce recycled hemodialysis wastewater suitable for use in irrigation [6]. The authors found that dialysate effluent is characterized by its high conductivity content. Otherwise, the chemical composition and bacterial biomass meet the standards set by the World Health Organization and the United Nations Food and Agriculture Organization for water used in irrigation $[2,3,6]$.

To attain the low conductivity values needed, the use of membranes ( $\mathrm{RO}$ and ultrafiltration) to treat hemodialysis effluents for reuse appears very promising. Such processes are currently widely used for treating various types of wastewaters and are effective in the elimination of trace organic compounds, bacteria and viruses $[2,33$, 
34]. The cost-benefit of this technology appears promising. The cost for treating hemodialysis wastewater to achieve quality suitable for irrigation using nanofiltration and RO is USD $0.70 / \mathrm{m}^{3}$ and USD $0.74 / \mathrm{m}^{3}$, respectively. Given the average cost of USD $1.00 / \mathrm{m}^{3}$ for seawater desalination, this could result in cost savings (or benefit) of $20-30 \%$ in comparison to desalination of seawater $[2,3]$.

\section{Future Approaches for Water Conservation}

Newer dialysis processes such as sorbent dialysate regeneration and online dialysate generation may help to dramatically reduce water use. Currently, one emerging sorbent system has been proven to reduce total dialysis related water use to 6 liters/treatment $[5,35,36]$. As these advances prove viable and/or become widely applicable, simple water conservation methods applied to standard dialysis equipment are essential.

\section{Benefits from Salvaging Water in Hemodialysis}

\section{Financial Savings}

Dialysis facilities are significant users of water. Reducing water use can lead to major capital savings $[2,3,6,12]$. Connor et al. [14], studied the saving potential of a 800 $1 / \mathrm{h}$ redirecting $\mathrm{RO}$ reject water system in Canterbury, UK. According to the authors, this system allowed a saving potential of GBP 7,500 each year. Also Tarrass et al. $[2,3]$, reported that treating spent dialysate for use in irrigation could result in cost savings of $20-30 \%$ in comparison to the desalination of seawater.

The financial costs will vary from unit to unit, and may dictate whether a water conservation project is viable. When performing a cost-benefit analysis, a number of parameters must be considered: capital equipment, operating and maintenance costs, and the volume of saved water $[2,3]$. In most cases, the costs will be small and the potential savings great.

\section{Environmental Impact}

Reducing Discharge of Wastewater

Wastewater generated by hemodialysis may have a significant impact on the environment due to its high conductivity and salinity $[2,3]$. However, the risk resulting from its discharge in bodies of water remains still underexplored. In the context of hemodialysis wastewater disposal in the ocean without treatment, pollution by hemodialysis effluents can be reduced substantially through recycling of water. Moreover, limiting discharge can indirectly help in maintaining water quality $[2,3]$.

\section{Reducing the Carbon Footprint}

The carbon footprint of dialysis is defined as the total amount of greenhouse gases produced to directly and indirectly support the dialysis facility's activities, usually expressed in equivalent tons of carbon dioxide $\left(\mathrm{CO}_{2}\right)$ [14]. The carbon footprint of the United States healthcare sector is estimated to be 546 million tons of $\mathrm{CO}_{2}$ per year, while that of the NHS in England is 18.6 million tons of $\mathrm{CO}_{2}$ (3\% of all greenhouse gas emissions in England) [37]

The contribution of kidney care to these footprints is presently unknown. However, wise use of water can help decrease carbon emission [38]. In the United Kingdom, Connor et al. [14] reported that the use of 14,400 liters of reject hemodialysis water per day in place of tapwater can result in saving $1,239.88 \mathrm{~kg}$ of $\mathrm{CO}_{2}$ equivalents per year.

\section{Conclusion}

Water is a vital aspect in hemodialysis. Using water wisely, through the approaches mentioned, will help us conserve this precious resource. Raising awareness of this concept among nephrologists is the crucial first step for achieving this goal. The International Society of $\mathrm{Ne}$ phrology and other regional or national societies can play leadership roles in promoting awareness for this green initiative in order to reduce our impact on our planet.

\section{References}

1 Tarrass F, Benjelloun M: Impact of water shortages in health and human development; in Briggs AC (ed): Water Shortages: Environmental, Economic and Social Impacts. New York, Nova Science Publishers, 2010.

-2 Tarrass F, Benjelloun M, Benjelloun O: Recycling wastewater after hemodialysis. An environmental analysis for alternative water sources in arid regions. Am J Kidney Dis 2008;52:154-158.
-3 Tarrass F: Research needs: treatment of hemodialysis wastewater for agricultural reuse. Water Environ Res 2010;82:291-293.

$\checkmark 4$ Hoenich NA, Levin R, Ronco C: Water for haemodialysis and related therapies: recent standards and emerging issues. Blood Purif 2010;29:81-85.

5 Amato RL: Water treatment for hemodialysis - updated to include the latest AAMI standards for dialysate (RD52:2004) continuing. Nephrol Nurs J 2005;32:151-167. 
6 Agar JW: Conserving water in and applying solar power to haemodialysis: 'Green Dialysis' through wiser resource utilisation. Nephrology DOI: 10.1111/j.1440-1797.2009. 01255.x.

7 Agar JW, Simmonds RE, Knight R, Somerville CA: Using water wisely: new, affordable, and essential water conservation practices for facility and home hemodialysis. Hemodial Int 2009;13:32-37.

8 Chung Hsiao Municipal Hospital: Water Conservation Measures at Chung Hsiao Municipal Hospital. Taipei city, Taiwan, China. http://www.ftis.org.tw/water/wra/2003 wra/2003wcopa/english/tmcsh.htm (accessed 2010).

9 Victoria Smart Water Fund and Norwest Health: Feasibility study of potential reuse of dialysis reject water. http://www.smartwater.com.au/projects/round6/nwhealth/Pages/nwhealth.aspx (accessed 2010).

10 Rosegrant MW, Cai X, Cline SA: World Water and Food to 2025: Dealing With Scarcity. Washington, International Food Policy Research Institute, 2002.

11 Intergovernmental Panel on Climate Change, 2001. Impacts, adaptation, and vulnerability; in McCarthy J, Canziani O, Leary N, Dokken D, White K (eds): Contribution of Working Group II to the Third Assessment Report of the Intergovernmental Panel on Climate Change. Cambridge, Cambridge University Press, 2001.

12 Dwight M: Can going green in dialysis save cash? http://www.renalbusiness.com/articles/going-green-in-dialysis.html (accessed 2010).

13 Agar JW: Reusing dialysis wastewater: The elephant in the room. Am J Kidney Dis 2008; 52:10-12.

14 Connor A, Milne S, Owen A, Boyle G, Mortimer F, Stevens P: Toward greener dialysis: a case study to illustrate and encourage the salvage of reject water. J Ren Care 2010;36: 68-72.

15 Printz J: Démarche écologique et réflexion des industriels en matiére de traitement de l'eau pour hémodialyse: le point de vue Gambro. Marseille, Association des Techniciens de Dialyse (ATD), 2009. http://www.dialyse. asso.fr/videos_marseille_session_2009. php4 (accessed April 8, 2010).
16 Troubleshooting RO Systems: Problem, Cause, Solution. http://www.roconn.com/ troubleshooting.html (accessed 2010).

17 Rohde JB, Maliekkal SJ: Dialysis system with flow regulation device. United States Patent Application 20100018923. http://www. freepatentsonline.com/y2010/0018923.htm (accessed 2010)

18 Kawasaki T, Uchino J, Shinoda T, Kawanishi $\mathrm{H}$ : Guidance of technical management of dialysis water and dialysis fluid for the Japan association for clinical engineering technologists. Blood Purif 2009;27(Suppl 1):41-49.

19 Ellis G: Water efficiency initiatives at Bendigo Health. Aust Hosp Eng 2007;43:28-31.

20 The Bays Hospital Group: Community water grants projects at Mornington and Hastings, summer 2008-09. www.thebays.com.au/ uploads/Summer_08_09_reduced.pdf (accessed April 8, 2010).

21 Walker D: Water recycling. Institute of Hospital Engineers, February 2007. http://www. ihea.org.au/energy/DAVID\%20IHEA\%20 DW\%20Presentation\%200207.pdf (accessed 2010).

22 Eastern Health: Eastern Health commitment to water conservation, January 2007 http://203.210.113.254/eastern/brochures/ EH\%20Water\%20Conservation\%20Strategies\%20January\%202007.pdf (accessed 2010).

23 Woodford R, Henderson C: Water saving designs North East Health Wangaratta. http:// www.ihea.org.au/energy/ROD\%20 Water\%20Saving\%20Designs\%20NHW.pdf (accessed 2010)

24 McGain F, Dillon L: Response to the Victorian government's climate change green paper from Western Health. Western Health, September 2009. http://www.climatechange. vic.gov.au/CA256F310024B628/0/4553AC6 281D585AFCA2576A1001E17B8/\$File/ Western+Health.pdf (accessed April 8, 2010).

25 Hoffman B: WaterSmart Innovations 2009 Sessions: Medical facilities and laboratories offer huge savings opportunities. http:/ www.watersmartinnovations.com/2009/ PDFs/F-1022.pdf (accessed 2010).

26 Tufts New England Medical Center Water Conservation at Tufts New England Medical Center (NEMC). http://www.h2e-online. org/pubs/tuftsh2o.doc, (accessed 2010).

27 The Canadian Association of Environmental Management (CAEM): Newsletter Spring 2008. http://www.caenvironmentalmanagement.com/caemnewsletter.html (accessed 2010).
28 Connor A, Milne S, Owen A, Boyle G, Stevens P: Toward greener dialysis: a case study to illustrate and encourage the salvage of reject water. J Ren Care 2010;36:68-72.

29 Chang Gung Memorial Hospital: Water Conservation Measures at Chang Gung Memorial Hospital, Linkou, Taiwan, China. http://www.ftis.org.tw/water/wra/2003 wra/2003wcopa/english/cgmh.htm (accessed 2010).

30 Office de L'eau de la Réunion: Remise des Trophées de l'eau 2009, dossier de presse. http://www.eaureunion.fr/fileadmin/user_ upload/Medias/13.03.09_Dossier_de_presse_trophees.pdf (accessed 2010).

31 Gouffrant F: La démarche écologique de la Clinique Delay. Association des Techniciens de Dialyse (ATD), Marseille 2009. http:// www.dialyse.asso.fr/videos_marseille_session_2009.php4 (accessed 2010).

32 USP Hospital La Colina, Sta Cruz de Tenerife. Noticias USP La Colina, abril 2009 - boletín $\mathrm{n}^{\circ}$ 33. http://www.usphospitales.com/ NEWSLETTER/200905/pdf/HCO\%20boletin\%20abril\%2009\%20.pdf.

33 Madaeni SS, Fane AG, Grohmann GS: Virus removal from water and wastewater using membranes. J Membr Sci 1995;102:65-75.

34 Grundestam J, Hellstrom D: Wastewater treatment with anaerobic membrane bioreactor and reverse osmosis. Water Sci Technol 2007;56:211-217.

35 Clark WR, Turk JE: The NxStage System One. Semin Dial 2004;17:167-170.

36 Hansen S: Sorbent dialysis in the third millennium. Nephrol News Issues 2006;20:4345.

37 NHS Carbon Reduction Strategy for England, 2009. Saving carbon, improving health. http://www.sdu.nhs.uk/downloadFile. php?doc_url=1237308334_qylG_saving_ carbon,_improving_health_nhs_carbon_ reducti.pdf (accessed 2010).

38 Clarke A, Grant N, Thornton J: Quantifying the energy and carbon effects of water saving. Environment Agency \& Energy Saving Trust 2009. http://www.energysavingtrust. org.uk/corporate/content/download/ 551015/1941299/version/2/file/i (assessed 2010). 